\title{
PENGARUH MODEL PEMBELAJARAN PPSI (PROSEDUR PENGEMBANGAN SISTEM INSTRUKSIONAL) TERHADAP HASIL BELAJAR SEJARAH
}

\author{
Putut Wisnu Kurniawan, S.Pd., M.Pd \\ Program Studi Pendidikan Sejarah STKIP Bandar Lampung \\ pututbukan@gmail.com
}

\begin{abstract}
Abstrak
Masalah dalam penelitian ini adalah rendahnya hasil belajar sejarah. Hal ini dikarenakan salah satunya kurang aktifnya siswa dalam pembelajaran. Tujuan penelitian ini adalah untuk mengetahui pengaruh model pembelajaran PPSI (Prosedur Pengembangan Sistem Instruksional) Terhadap hasil belajar sejarah siswa kelas X SMA Persada Bandar Lampung semester genap tahun pelajaran 2014/2015. Populasi dalam penelitian ini berjumlah 110 siswa dan sampel dalam penelitian ini berjumlah 27 siswa. Teknik sampling dalam penelitian ini adalah Cluster Random Sampling. Pengumpulan data dilakukan dengan menggunakan metode eksperimen dan teknik tes sebagai metode pokok, serta teknik dokumentasi dan studi kepustakaan sebagaimana metode pelengkap. Analisis data dilakukan dengan menggunakan rumus $t$ tes. Berdasarkan hasil analisis data diperoleh $t_{\text {hit }}=5,24$, sedangkan untuk taraf signifikan $5 \% \quad t_{\text {daf }}=$ 2,00. Rata-rata hasil belajar siswa yang diajar menggunakan model pembelajaran PPSI (Prosedur Pengembangan Sistem Instruksional) yaitu 83. Sedangkan rata-rata hasil belajar sejarah siswa yang diajar menggunakan model pembelajarn konvensional yaitu 73. Dengan demikian dapat disimpulkan bahwa ada pengaruh penggunaan model pembelajaran PPSI (Prosedur Pengembangan Sistem Instruksional) terhadap hasil belajar sejarah siswa kelas X SMA Persada Bandar Lampung semester genap tahun pelajaran 2014/2015.
\end{abstract}

Kata kunci: Model Pembelajaran PPSI (prosedur pengembangan sistem instruksional), Hasil Belajar Sejarah.

\begin{abstract}
The problem in this research is the low of students' learning outcomes of history. It is caused by the students' initiative in teaching and learning process. The purpose of this study was to determine the learning model ITS (Instructional Systems Development Procedure) learning model towards students' learning outcomes of history at tenth grade of SMA PERSADA Bandar Lampung in academic year 2014/2015. The population in this research was 110 students and the sample was 27 students. In getting the sample, the writer used a cluster random sampling. The data in this research were collected by using experimental methods and testing technique as the main method, as well as technical documentation and study of literature as the supporting method. In analyzing the data, the writer used t-test formula. Based on the analysis of data, it is obtained $t$ hit $=5.24$, while for the significant level of $5 \% t$-daf $=2.00$. The average score of the students who learn history through ITS (Instructional Systems Development Procedure) learning model is 83 . While the average score of students who learn history through conventional technique is 73 . It can be concluded that, there is influence of learning model using ITS (Instructional Systems Development Procedure) towards students' learning outcomes of history at tenth grade of SMA PERSADA Bandar Lampung in academic year 2014/2015.
\end{abstract}

Keyword: ITS (Instructional Systems Development Procedure) learning model, learning outcomes of history. 


\section{PENDAHULUAN}

Pendidikan memiliki peran yang sangat penting dalam mencedaskan kehidupan bangsa. Oleh karena itu perlu adanya usaha untuk meningkatkan kualitas pendidikan. Peningkatan kualitas pendidikan dapat dilihat dari keberhasilan belajar siswa. Namun demikian masih banyak hasil belajar siswa yang masih rendah. Hal ini disebabkan oleh faktor-faktor yang menjadi penghambat hasil belajar siswa menjadi rendah. Diantaranya yaitu, kurangnya minat belajar siswa dan kurangnya partisipasi siswa dalam belajar mengajar. Kebanyakan siswa lebih mementingkan kegiatan-kegiatan yang tidak ada manfaatnya. Seperti kebanyakan bermain, khususnya di luar sekolah, kemudian kurangnya minat siswa dalam membaca buku-buku seperti pelajaran sejarah, kebanyakan siswa lebih cenderung untuk membaca buku-buku yang tidak ada manfaatnya seperti komik, novel, dan lain-lain.

Selain faktor-faktor di atas, siswa kurang aktif dalam proses pemebelajaran. Siswa hanya mengandalkan guru dalam kegiatan belajar mengajar. Faktor lain yang menyebabkan hasil belajar siswa menjadi rendah, yaitu kurangnya model pembelajaran yang tepat yang diterapkan seorang pendidik kepada peserta didik. Dengan adanya model pembelajaran yang tepat, maka akan menciptakan motivasi belajar siswa. Selain model pembelajaran, penetapan tujuan pembelajaran merupakan syarat mutlak bagi guru untuk memilih model pembelajaran yang akan digunakan di dalam penyajian materi pembelajaran. Tujuan pembelajaran merupakan sasaran yang hendak dicapai pada akhir pembelajaran, serta kemampuan yang harus dimiliki siswa. Dalam proses pembelajaran siswalah yang menjadi subjek, siswa yang bertindak sebagai pelaku kegiatan belajar.

Dalam observasi yang dilakukan penulis di SMA Persada Bandar Lampung dapat dilihat siswa masih pasif dan hanya mengandalkan guru untuk menjelaskan materi pelajaran, sehingga menyebabkan siswa sulit untuk mengembangkan daya nalarnya. Siswa menganggap pelajaran sejarah adalah pelajaran yang kurang menarik, sehingga hal itu menyebabkan hasil belajar mereka menjadi rendah. Hal tersebut dapat diketahui bahwa masih banyak siswa yang mendapat nilai dibawah KKM. Dengan KKM 75 yang sudah ditentukan dari 110 siswa hanya 20 siswa yang berhasil mencapai KKM. sehingga dapat disimpulkan bahwa hasil belajar siswa kelas $X$ rendah.

Beberapa model pembelajaran telah diberikan oleh guru juga belum variatif sehingga perlu adanya model pembelajaran baru untuk meningkatkan hasil dan minat belajar siswa. Alasan 
tersebut yang menarik penulis untuk melakukan penelitian dengan judul “Pengaruh Model Pembelajaran PPSI (Prosedur Pengembangan Sistem Instruksional) Terhadap Hasil Belajar Sejarah Siswa Kelas X SMA Persada Bandar Lampung Semester Genap Tahun Pelajaran 2014/2015”. Penelitian ini ingin mengetahui pengaruh penggunaan model pembelajaran PPSI

(Prosedur Pengembangan Sistem Instruksional) terhadap hasil belajar mata pelajaran Sejarah siswa kelas $X$ semester genap SMA Persada Bandar Lampung Tahun Pelajaran 2014/2015.

\section{Pengertian Belajar}

Menurut Hilgard, Belajar adalah proses perubahan melalui kegiatan atau prosedur latihan baik latihan di dalam laboratorium maupun dalam lingkungan alamiah. (Wina Sanjaya, 2009:112). Belajar merupakan peristiwa sehari-hari di sekolah. Belajar merupakan hal yang kompleks. Kompleksitas belajar tersebut dapat dipandang dari dua subjek, yaitu dari siswa dan dari guru. Siswa mengalami proses mental dalam menghadapi bahan belajar. "Belajar merupakan proses internal yang kompleks. Yang terlibat dalam proses internal tersebut adalah seluruh mental yang meliputi ranah-ranah kognitif, afektif dan psikomotorik" (Dimyati, dkk, 2009:17).

Dari pendapat diatas maka dapat disimpulkan bahwa belajar adalah kegiatan individu memperoleh pengetahuan, prilaku dan keterampilan dengan cara mengolah bahan belajar. Dalam belajar tersebut individu menggunakan ranah kognitif, afektif dan psikomotorik makin bertambah baik.

\section{Model Pembelajaran PPSI (Prosedur Pengembangan Sistem Instruksional)}

PPSI (Prosedur Pengembangan Sistem Instruksional) menurut Hamzah adalah sistem yang saling berkaitan dari satu instruksi yang terdiri atas urutan, desain tugas yang progresif bagi individu dalam belajar, agar setiap individu dapat meraih keberhasilan dalam proses belajar mengajar sesuai dengan tujuan PPSI itu sendiri. (Hamzah B.Uno, 2007:81)

PPSI (Prosedur Pengembangan Sistem Instruksional) menggunakan pendekatan sistem yang mengutamakan adanya tujuan yang jelas, sehingga dapat dikatakan bahwa PSSI merujuk pada pengertian sebagai suatu sistem, yaitu sebagai kesatuan yang terorganisasi, yang terdiri atas sejumlah komponen yang saling berhubungan satu dengan yang lainya dalam rangka mencapai tujuan yang diinginkan. Sebagai suatu sistem, pembelajaran mengandung sejumlah komponen, seperti tujuan, materi, metode, alat dan evaluasi yang semuanya berinteraksi satu dengan yang lainya untuk mencapai tujuan pembelajaran yang telah ditetapkan. (Rusman, 2012:148). Rusman lebih lanjut menjelaskan PPSI merupakan model 
pembelajaran yang menerapkan suatu sistem untuk mencapai tujuan pembelajaran secara efektif dan efesien. Dijelaskan lebih lanjut menurut Rusman ada lima langkah pokok dari pengembangan model PPSI yaitu:

1. Merumuskan tujuan pembelajaran

2. Pengembangan alat evaluasi (menentukan jenis tes yang akan digunakan)

3. Menentukan kegiatan belajar mengajar (menetapkan kegiatan pembelajaran yang akan di tempuh)

4. Merencanakan kegiatan belajar mengajar (Merumuskan Materi pelajaran dan memilih sumber yang akan di gunakan)

5. Pelaksanaan (Mengadakan pretest, menyampaikan materi pelajaran, mengadakan posttest dan revisi). (Rusman, 2012:148-149)

Adapun langkah-langkah pelaksanaan model PPSI dalam kegiatan belajar mengajar adalah sebagai berikut :

1. Mengadakan Pretest (Tes Awal)

Fungsi tes awal ini adalah untuk memperoleh informasi tentang kemampuan siswa, sebelum mereka mengikuti program pembelajaran yang telah disiapkan.

2. Menyampaikan Materi Pembelajaran Sebelum menyampaikan materi pelajaran, hendaknya guru menjelaskan dulu kepada siswa tujuan/kompetensi yang akan dicapai, sehingga mereka mengetahui kemampuan kemampuan setelah mengikuti pelajaran.

3. Mengadakan Post test

Post test diberikan setelah selesai mengikuti program pembelajaran. Tes yang diberikan identik dengan yang diberikan pada tes awal, jadi bedanya terletak pada waktu dan fungsinya. (Rusman, 2012:150:151)

Dapat disimpulkan bahwa PPSI (Prosedur Pengembangan Sistem Instruksional) merupakan suatu langkahlangkah pengembangan dan pelaksanaan pembelajaran sebagai suatu sistem yang terdiri atas sejumlah komponen yang saling berhubungan satu sama lain dalam rangka untuk mencapai tujuan yang efektif dan efesien.

\section{Pengertian Hasil Belajar}

Evaluasi hasil belajar merupakan proses untuk menentukan nilai belajar siswa melalui kegiatan penilaian dan pengukuran hasil belajar. (Dimyati, dkk 2009:200). Hasil belajar adalah kemampuan-kemampuan yang dimiliki siswa setelah ia menerima pengalaman belajarnya. (Nana Sudjana, 2009:22)

Dari pendapat diatas dapat disimpulkan bahwa hasil belajar merupakan suatu puncak proses belajar. Hasil belajar tersebut terjadi terutama berkat evaluasi guru. Dan kemampuan yang dimiliki siswa setelah menerima pengalaman belajarnya. Menurut W.S. Winkel (1994:240) adapun faktor-faktor yang dapat mempengaruhi hasil belajar 
dapat digolongkan menjadi tiga kelompok, yaitu :

1. Faktor dari pihak murid, terdiri dari, faktor intelegensi, faktor hasil belajar, faktor kondisi fisik.

2. Faktor dari pihak guru, yaitu faktor pengetahuan guru, faktor sikap guru

3. Faktor Intitusi lain yaitu, faktor kurikulum, faktor jadwal kurikulum, faktor pembagian tugas, faktor pengelompokan siswa dan faktor fasilitas siswa.

Berbeda dengan pendapat Nasution, faktor yang mempengaruhi hasil belajar menurut S. Nasution (2009:38) adalah bakat untuk mempelajari suatu mutu pelajaran, kesanggupan untuk mempelajari pembelajaran, ketekunan, waktu yang disediakan untuk belajar.

Menurut Oemar Hamalik (2009:93) faktor lain yang mempengaruhi pencapaian hasil belajar yaitu:

1. Faktor pertumbuhan ialah pertambahan secara kuantitatif dari substansi ataustruktur yang umumnya ditandai dengan perubahan biologis pada diri yang menuju kematangan.

2. Faktor kematangan ialah tingkat atau keadaan yang harus dicapai dalam proses perkembangan perorangan sebelum ia dapat melakukan sebagaimana mestinya pada bermacam-macam tingkat pertumbuhan mental sosial dan emosional.

3. Faktor pengembangan menggambarkan perubahan kualitas diri seseorang, yakni adanya perubahan dalam struktur, kapasitas, fungsi dan efisiensi.

4. Perkembangan normal dilihat dari segi pola perkembangan individu siswa seperti, yang lebih dulu pandai berjalan sedangkan siswa yang lain lebih cepat pandan berbicara.

Berdasarkan uraian diatas, faktor yang dapat mempengaruhi hasil belajar siswa, diantaranya ada faktor yang datangnya dari dalam diri siswa atau disebut sebagai faktor interen dan faktor yang datangnya dari luar diri siswa disebut sebagai faktor eksteren.

METODE PENELITIAN

Pada penelitian ini penulis menggunakan metode eksperimen (experimental Method). Dalam penelitian ini terdapat dua variabel, yaitu: variabel $X$ adalah penggunaan model pembelajaran PPSI (Prosedur Pengembangan Sistem Instruksional) dan variabel $Y$ adalah hasil belajar Sejarah.

Populasi dalam penelitian ini adalah Siswa Kelas $X$ Semester genap SMA Persada Bandar Lampung Tahun Pelajaran 2014/2015 berjumlah 110 siswa, dan sampel dalam penelitian ini adalah kelas X.1 dengan jumlah siswa 27 sebagai kelas eksperimen dan kelas X.2 dengan jumlah siswa 26 sebagai kelas kontrol. Pengambilan sampel dilakukan dengan teknik cluster random sampling.

Teknik pokok yang digunakan dalam penelitian ini digunakan teknik tes, yaitu untuk melihat dan menganalisis 
pengaruh

penggunaan

model

pembelajaran

PPSI

(Prosedur

Pengembangan Sistem Instruksional)

terhadap hasil belajar Sejarah. Teknik pelengkap yaitu teknik dokumentasi, teknik kepustakaan dan observasi.

\section{HASIL PENELITIAN DAN PEMBAHASAN}

\section{Uji Validitas Alat Ukur}

Suatu alat ukur dikatakan valid apabila alat ukur tersebut dapat mengukur apa yang hendak diukur secara tepat. Hal ini sesuai dengan pendapat Sutrisno Hadi (2005:102) yang menyatakan: "Validitas adalah ketelitian dan kejituhan suatu alat ukur". Dalam penelitian ini uji validitas tidak dilakukan dengan uji coba, mengingat faktor waktu dan biaya yang tidak memungkinkan, sehingga untuk uji validitas tersebut penulis lakukan dengan cara "Logocal Validity" (dengan melihat susunanya) dengan cara "Judgment". yaitu dengan cara mengonsultasikan kepada beberapa ahli dalam bidang penelitian baru kemudian diadakan revisi seperlunya.

\section{Uji Reliabilitas Alat Ukur}

Berdasarkan hasil perhitungan tentang reabilitas alat ukur, dengan menggunakan teknik belah dua dengan menggolongkan skor yang bernomor ganjil genap, kemudian di kolerasikan dengan menggunakan rumus Correlation Product Moment. selanjutnya di analisis menggunakan rumus Sperman Brown diperoleh $r_{\mathrm{gg}}=0,77$. kemudian untuk nilai $r_{\text {gg }}$ hasil uji coba tes berada pada interval 0,600 - 0,800 sehingga termasuk kategori sedang, dengan demikian soal tes tersebut dapat digunakan dan dipakai sebagai alat ukur dalam penelitian ini.

Setelah dilakukan uji coba alat ukur (tes) yang mempunyai reabilitas sedang, maka soal itu diujikan kepada sampel penelitian untuk mengetahui pengaruh model pembelajaran PPSI (Prosedur Pengembangan Sistem Instrusional) dalam meningkatkan hasil belajar Sejarah siswa kelas $X$ semester genap SMA Persada Bandar Lampung Tahun Pelajaran 2014/2015. Selanjutnya dilakukan analisis data dan hasilnya adalah sebagai berikut.

\section{Analisis Data}

Uji normalitas data kelas eksperimen Kriteria uji: Terima $\mathrm{H}_{0}$ jika $X_{\text {hit }}^{2}<x^{2}(1-\alpha)(k-3) \chi_{\text {hit }}^{2}<\chi_{\text {daf }}^{2} \quad$ untuk taraf signifikan $5 \%$ didapat 4,01<7,81 sehingga Ho diterima berarti data berasal dari populasi yang berdistribusi normal. Uji normalitas data kelas control dengan kriteria uji Terima $\mathrm{H}_{0}$ jika $X_{\text {hit }}^{2}<x^{2}(1-\alpha)(k-3) \chi_{\text {hit }}^{2}<\chi_{\text {daf }}^{2} \quad$ untuk taraf signifikan 5\% didapat 4,65 7,81 sehingga Ho diterima berarti data berasal dari populasi yang berdistribusi normal.

Uji Homogenitas Varians dan Uji Kesamaan Dua Rata-Rata

Diketahui $\mathrm{F}_{\text {hit }}<\mathrm{F}_{\text {daf }}$ untuk taraf signifikan $5 \%$ didapat $1,19<1,22$ dan 
untuk taraf $1 \%$ didapat $1,22<2,20$ berarti kedua data mempunyai varians yang homogen. Sedangkan uji kesamaan dua rerata menunjukan hasil perhitungan $t_{\text {daf }}$ untuk $a=5 \%=2,00$ lebih kecil dari $t_{\text {hit }}=5,24$. Jadi $t_{\text {hit }}>t_{\text {daf }}\left(1-\frac{1}{2} a\right)$ atau $5,24>2,00$ tidak terpenuhi, sehingga hipotesis $H_{O} 1$ ditolak yang berarti ada perbedaan rata-rata hasil belajar sejarah siswa yang diajar menggunakan model pembelajaran PPSI lebih besar dibandingkan dengan yang diajar tidak menggunakan model pembelajaran PPSI.

\section{Uji Perbedaan Dua Rata-Rata}

Dari hasil perhitungan di atas menunjukan bahwa $a=5 \%$ diperoleh nilai $t_{\text {hit }}=5,24>t_{\text {daf }}=2,00$. Jadi dalam hal ini hipotesis $H_{0}$ ditolak yang berarti rata-rata hasil belajar sejarah siswa yang diajar menggunakan model pembelajaran PPSI lebih tinggi dibandingkan hasil belajar sejarah siswa yang diajar tidak menggunakan model pembelajaran PPSI. Dengan demikian model pembelajaran PPSI berpengaruh positif atau dapat meningkatkan hasil belajar sejarah.

Berdasarkan analisis data yang telah dilakukan terdapat perbedaan hasil belajar sejarah antara siswa yang diajar menggunakan model pembelajaran PPSI dengan siswa yang diajar tidak menggunakan model pembelajaran PPSI. Perbedaan tersebut dapat dilihat dari rata-rata hasil belajar sejarah yang telah diperoleh siswa. Rata-rata hasil belajar sejarah siswa yang diajar menggunakan model pembelajaran PPSI adalah 83,29 dan hasil belajar sejarah siswa yang diajar tidak menggunakan model pembelajaran PPSI adalah 73,26. dengan demikian perbedaan tersebut secara nyata dapat dilihat dari selisih hasil yang dicapai siswa sebesar 10,03.

Penyebab dari perbedaan hasil yang dicapai siswa tersebut karena ada perlakuan yang berbeda dimana ada siswa yang diajar menggunakan model pembelajaran PPSI dan di pihak lain ada siswa yang diajar tidak menggunakan model pembelajaran PPSI. Oleh karenanya dalam setiap pembelajaran sejarah diharapkan guru dapat menggunakan model pembelajaran PPSI. Berdasarkan uraian tersebut di atas, maka hipotesis yang diajukan dalam penelitian ini yaitu ada pengaruh penerapan model pembelajaran PPSI (Prosedur Pengembangan Sistem Instruksional) terhadap hasil belajar sejarah siswa kelas $X$ semester genap SMA Persada Bandar Lampung tahun Pelajaran 2014/2015. Teruji kebenaranya dan diterima. Berarti dari 27 orang siswa yang diajar menggunakan model pembelajaran PPSI (Prosedur Pengembangan Sistem Instruksional) dibandingkan dengan 26 orang siswa yang diajar tidak menggunakan model pembelajaran PPSI lebih tinggi 10,03. 


\section{PENUTUP}

\section{Simpulan}

Berdasarkan hasil analisis data bahwa siswa yang diajar menggunakan model pembelajaran PPSI rata-rata hasil belajarnya lebih tinggi dibandingkan dengan siswa yang tidak menggunakan model pembelajaran PPSI, hal tersebut di karenakan ada perlakuan yang berbeda dimana ada kelas yang diajar menggunakan model pembelajaran PPSI dan di pihak lain ada kelas yang diajar tidak menggunakan model pembelajaean PPSI. Nilai rata-rata hasil belajar kelas eksperimen mencapai nilai 83,29 sedangkan nilai rata-rata kelas kontrol yang diajar tidak menggunakan model pembelajaran PPSI nilai rata-ratanya adalah 73,26.

Jadi dari hasil perhitungan diatas menunjukan bahwa nilai $t_{\text {hit }}=5,24$ dan $t_{\text {daf }(0,975)}=2,00$ atau 5,24 > 2,00 dengan $\mathrm{n}=53$ pada taraf $5 \%$ jadi dalam hal ini hipotesis $H_{0}$ ditolak yang berarti rata-rata hasil belajar sejarah siswa yang diajar menggunakan model pembelajaran PPSI lebih tinggi dibandingkan dengan hasil belajar siswa yang diajar tidak menggunakan model pembelajaran PPSI. Berdasarkan hal tersebut dapat disimpulkan bahwa penggunaan model pembelajaran PPSI (Prosedur Pengembangan Sistem Instruksional) berpengaruh terhadap hasil belajar sejarah siswa kelas X SMA Persada Bandar Lampung tahun pelajaran 2014/2015.

\section{DAFTAR PUSTAKA}

Arikunto, S. (2006). Dasar-dasar Evaluasi Pendidikan. Jakarta: Bumi Aksara.

Arikunto, S. (2008). Prosedur Penelitian Suatu Pendekatan Praktek, Jakarta: Rineka Cipta.

Dimyati, Mudjiono, (1999). Belajar dan Pembelajaran, Jakarta: Rineka Cipta.

Gazalbi, Sidi, (1991). Pengantar Sejarah Sebagai Ilmu, Jakarta: Baharata Karya.

Hastuti, (2014). Model Pembelajaran PPSI, diakses pada 19 Febuari 2015.

http: / / tugas2kampus.wordpress.c om

Hadi, Sutrisno, (2003). Metodologi Research, Yogyakarta: Universitas Gaja Mada.

Hamalik, Oemar, (2006). Perencanaan Pengajaran Bersadarkan Pendekatan Sistem, Jakarta: Bumi Aksara.

Hamalik, Oemar, (2009). Proses Belajar Mengajar, Jakarta: Bumi Aksar

Rusman, (2012). Model-model Pembelajaran: Seri Manajemen Sekolah Bermutu. Jakarta: Raja Grafindo persada.

S. Nasution, (2009). Proses Belajar Mengajar, Jakarta: Bumi Aksara.

Sanjaya, Wina. (2006). Strategi Pembelajaran: Berorientasi Standar Proses Pendidikan. Jakarta: Kencana Prenada Media Group.

Sudjana, (2005). Metode Statistika. Bandung: Transito.

Sugiono, (2010). Metode Penelitian Kuantitatif, Kualitatif, Kualitatif dan $r \& d$, Bandung: Alfabeta.

Uno, Hamzah, (2007). Model Pembelajaran, Jakarta: Bumi Aksara. 
Wardaya, (2006). Aspirasi, Surakarta:

Widia Duta Grafika.

Winkel, W.S. (1994). Psikologi Pendidikan

dan Evaluasi, Jakarta: Gramedia.

Syarif, (2011). Model Perencanaan

Pembelajaran PPSI, diakses pada

21 April 2015.

http://syariftugas.blogspot.com 